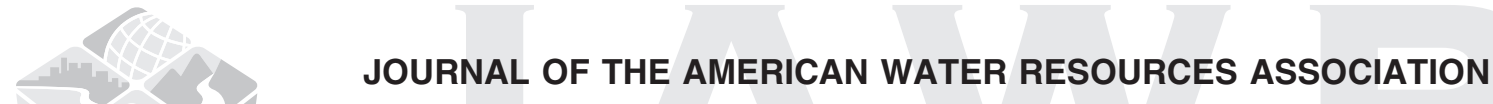

Vol. 46, No. 4

AMERICAN WATER RESOURCES ASSOCIATION

August 2010

\section{RECOVERY OF SEDIMENT CHARACTERISTICS IN MORAINE, HEADWATER STREAMS OF NORTHERN MINNESOTA AFTER FOREST HARVEST ${ }^{1}$}

\author{
Eric C. Merten, Nathaniel A. Hemstad, Randall K. Kolka, \\ Raymond M. Newman, Elon S. Verry, and Bruce Vondracek ${ }^{2}$
}

\begin{abstract}
We investigated the recovery of sediment characteristics in four moraine, headwater streams in north-central Minnesota after forest harvest. We examined changes in fine sediment levels from 1997 (preharvest) to 2007 (10 years postharvest) at study plots with upland clear felling and riparian thinning, using canopy cover, proportion of unstable banks, surficial fine substrates, residual pool depth, and streambed depth of refusal as response variables. Basin-scale year effects were significant $(p<0.001)$ for all responses when evaluated by repeated-measures ANOVAs. Throughout the study area, unstable banks increased for several years postharvest, coinciding with an increase in windthrow and fine sediment. Increased unstable banks may have been caused by forest harvest equipment, increased windthrow and exposure of rootwads, or increased discharge and bank scour. Fine sediment in the channels did not recover by summer 2007, even though canopy cover and unstable banks had returned to 1997 levels. After several storm events in fall 2007, 10 years after the initial sediment input, fine sediment was flushed from the channels and returned to 1997 levels. Although our study design did not discern the source of the initial sediment inputs (e.g., forest harvest, road crossings, other natural causes), we have shown that moraine, headwater streams can require an extended period (up to 10 years) and enabling event (e.g., high storm flows) to recover from large inputs of fine sediment.
\end{abstract}

(KEY TERMS: environmental impacts; riparian ecology; forests; headwaters; rivers/streams; sediment; erosion; watershed management.)

Merten, Eric C., Nathaniel A. Hemstad, Randall K. Kolka, Raymond M. Newman, Elon S. Verry, and Bruce Vondracek, 2010. Recovery of Sediment Characteristics in Moraine, Headwater Streams of Northern Minnesota After Forest Harvest. Journal of the American Water Resources Association (JAWRA) 46(4):733-743. DOI: $10.1111 / \mathrm{j} .1752-1688.2010 .00445 . \mathrm{x}$

\section{INTRODUCTION}

The effects of fine sediment on stream ecosystems have been well documented and can include increased turbidity, reduced ability of aquatic organisms to feed, clogged gills of fish and macroinvertebrates, smothered eggs and larvae, and homogenization of habitats (Waters, 1995; Sweka and Hartman, 2001). Fine sediment can enter streams through a variety of mecha-

\footnotetext{
${ }^{1}$ Paper No. JAWRA-09-0110-P of the Journal of the American Water Resources Association (JAWRA). Received July 20, 2009; accepted March 13, 2010. ( $) 2010$ American Water Resources Association. Discussions are open until six months from print publication.

${ }^{2}$ Respectively, Senior Research Specialist, Department of Biology, University of Wisconsin - Eau Claire, 105 Garfield Avenue, Eau Claire, Wisconsin 54702; Instructor, Department of Biology, Inver Hills Community College, 2500 East 80th St., Inver Grove Heights, Minnesota 55076; Team Leader and Research Soil Scientist, USDA Forest Service, Northern Research Station, 1831 Hwy. 169 East, Grand Rapids, Minnesota 55744; Professor, Department of Fisheries, Wildlife, and Conservation Biology, University of Minnesota, 1980 Folwell Avenue, St. Paul, Minnesota 55108; Chief Hydrologist, Ellen River Partners, Inc., Grand Rapids, Minnesota 55744; and Assistant Unit Leader and Adjunct Professor, USGS, Minnesota Cooperative Fish and Wildlife Research Unit, University of Minnesota, 1980 Folwell Avenue., St. Paul, Minnesota 55108 (E-Mail/Merten: mertenec@uwec.edu).
} 
nisms, including eolian processes, landslides, overland flow, bank erosion, or delivery from roads (Chamberlin et al., 1991; Wondzell, 2001; Broadmeadow and Nisbet, 2004). However, sediment inputs from eolian processes are minor in temperate forests (Steedman and France, 2000), and landslides are uncommon in streams with hillslopes under 35 degrees (Johnson et al., 2007).

Forest harvest can also contribute excess sediment to streams; excess sediment can manifest as increases in total suspended sediment (Gomi et al., 2005), streambed aggradation (Keim and Schoenholtz, 1999), or the proportion of surficial fine substrates (Davies and Nelson, 1994; Thompson et al., 2009). For example, suspended sediment during storm-flow events increased significantly in a Fiji catchment after salvage logging and slash burning; much of the sediment was mobilized from new logging roads and landing areas (Waterloo et al., 2007). Similarly, thinning only $11 \%$ of the standing timber volume with horse skidding produced a significant increase in suspended sediment to a stream in Turkey (Serengil et al., 2007a). Hydrographs also indicated significantly more storm flow in both study areas (Serengil et al., 2007b; Waterloo et al., 2007).

Increased flow can take decades to recover after forest harvest (Moore and Wondzell, 2005) and may lead to increased bank erosion (Brooks et al., 1997). In a forest harvest study in British Columbia, peak snowmelt discharge remained above preharvest levels for the five-year duration of the study (Macdonald et al., 2003). Verry (2004) noted that channel-forming flows double or triple after $60 \%$ of a catchment is converted from forest to nonforest conditions in the upper Midwest; however, little work has been carried out on the effect of elevated flows on sediment inputs.

Input processes aside, few studies have examined the recovery of streams after large inputs of sediment (Gomi et al., 2005). In one case, the bed load of fine sediment required more than two years to return to natural levels after road-improvement activities (Kreutzweiser and Capell, 2001), and in another case sediment eroded from logging roads and skid trails was stored in stream channels for 3.4 years (Gomi et al., 2006). In a review of available studies, Gomi et al. (2005) noted that sediment yield usually recovers within one to six years postharvest, barring landslides. Previous research in Minnesota (Merten, 1999; Hemstad and Newman, 2006; Hemstad et al., 2008) suggests that levels of fine sediment can increase significantly after forest harvest. However, a need exists for longerterm studies spanning more than a few years to determine how long fine sediment will persist in channels.

Our objective was to evaluate changes in fine sediment in four headwater streams following timber harvesting in riparian areas in the Sugar Hills moraine of north-central Minnesota. We predicted that fine sediment loading would increase after forest harvest, but that sediment levels would return to preharvest conditions within 10 years. Hemstad et al. (2008) suggested that basin-scale factors (responding broadly to weather patterns, discharge regimes, and geomorphic attributes) were more important to sediment in our study area than plot-level factors (responding to harvest treatments in the immediate area). Although our study did not discern between changes due to forest harvest, road crossings, or natural causes, it did evaluate recovery at the basin scale after a large input of fine sediment.

\section{STUDY AREA}

Twelve study plots were located in the Pokegama Creek system in north-central Minnesota $\left(47^{\circ} 8.039^{\prime} \mathrm{N}\right.$, $\left.93^{\circ} 37.405^{\prime} \mathrm{W}\right)$; the basin included four small, forested subcatchments with moraine hills rising 5-7 m above the valley floor and hillslopes of 1-30\% (Figure 1). One plot was on an intermittent tributary and was thus omitted from analyses. Soils and parent material in the Sugar Hills moraine were loamy sands with gravel lenses and cobble/boulder inclusions (Nyberg, 1987). The upland soils were fertile and well-drained, supporting late successional forests of sugar maple (Acer saccharum Marsh) and basswood (Tilia americana Linnaeus). Early successional forests within 10 years of clearcut logging treatments included: paper birch (Betula papyrifera Marsh), aspen (Populus tremuloides and Populus grandidenta), and balsam fir [Abies balsamea (Linnaeus) Miller]. Riparian forests at the floodplain elevation included black ash (Fraxinus nigra Marsh), along with sugar maple and basswood and remnant early succession species (about $10 \%$ of basal area). Preharvest riparian forests in 1997 averaged $30 \mathrm{~m}^{2}$ /ha of basal area (Palik et al., 2003).

The subcatchments of the four study streams varied in size from 129 to 281 ha (Table 1). Harvested study plots accounted for $2-11 \%$ of their respective subcatchments, whereas open areas or young forest ( $<16$ years) in the catchment accounted for 25-49\%. The slope, width, and mean depth of the study streams were measured at each plot and immediately upstream, along with tree basal area in and above the plots (Table 2). Channel gradients were relatively steep (0.7-3.5\%, one tributary was $7.2 \%$ ) because they drained glacial moraine hills. Sediment in the streams was predominately fine sand, as evidenced by the diameter of the 50th percentile of all particles $\left(D_{50}\right)$. The substrate contained gravel and cobble sizes at the 84th percentile $\left(D_{84}\right)$ where channels had a steeper gradient. Cobble and small boulders were concentrated 


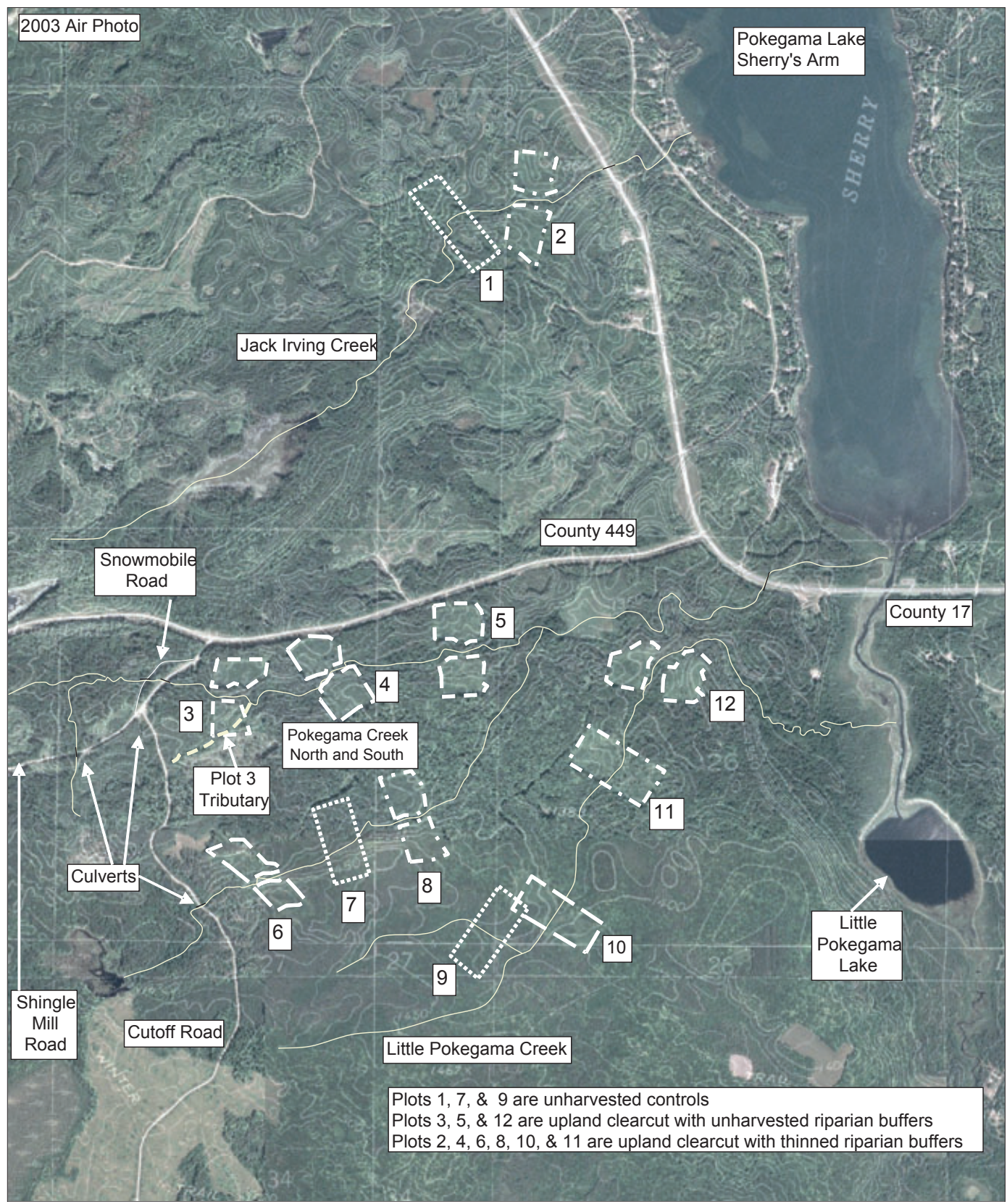

FIGURE 1. Pokegama Creek System $(3.62 \times 4.3 \mathrm{~km})$ Showing Riparian Plots (numbered), Stream Channels and Tributaries, Roads, and Beaver Impoundments. Figure by Doug Kastendick.

in the glacial drift of Little Pokegama Creek (Table 2). A paved road ran approximately $250 \mathrm{~m}$ to the north and parallel to one stream (Pokegama Creek North), and an existing gravel road with culverts crossed two of the streams (Pokegama Creek North and Pokegama Creek South) just upstream from the study plots. Two additional culvert crossings were farther upstream on Pokegama Creek North (Figure 1). Beaver dams and impoundments were present below the confluence of Pokegama Creek North and Pokegama Creek South, and well upstream of Plots 1 and 2 on Jack Irving Creek (Figure 1).

\section{METHODS}

\section{Harvested Study Plots}

Harvest treatments were replicated throughout the four subcatchments. Harvest treatments spanned the stream at each plot ( 4.9 ha, with 2.45 ha on each side of the stream) and included: unharvested controls $(n=2), 30-\mathrm{m}$ unharvested riparian buffer with the upland clearcut $(n=3)$, or thinned to $12.3 \mathrm{~m}^{2} / \mathrm{ha}$ within a $30-\mathrm{m}$ riparian strip with the upland clearcut 
Merten, Hemstad, Kolka, Newman, Verry, and Vondracek

TABLE 1. Watershed Areas for Each Study Stream, Open or Young Forest Area, and the Area of Harvested Plots.

\begin{tabular}{|c|c|c|c|c|c|c|c|}
\hline & $\begin{array}{c}\text { Total } \\
\text { (ha) }\end{array}$ & $\begin{array}{l}1977 \text { Open } \\
\text { (ha) }\end{array}$ & $\begin{array}{l}2003 \text { Open } \\
\text { (ha) }\end{array}$ & $\begin{array}{c}2003 \text { Open } \\
(\%)\end{array}$ & Study Plots & $\begin{array}{c}\text { Harvest } \\
\text { Plots (ha) }\end{array}$ & $\begin{array}{c}\text { Harvest } \\
\text { Plots (\%) }\end{array}$ \\
\hline Jack Irving & 281 & 99.8 & 138.5 & 49 & 1,2 & 4.8 & 2 \\
\hline Pokegama North & 168 & 23.7 & 42.8 & 25 & $3,4,5$ & 11.7 & 7 \\
\hline Pokegama South & 135 & 52.6 & 62.8 & 47 & $6,7,8$ & 7.9 & 6 \\
\hline Little Pokegama & 129 & 14.8 & 23.8 & 18 & $9,10,11,12$ & 13.7 & 11 \\
\hline
\end{tabular}

Notes: Areas are based on 1977 and 2003 air photos with on-site reconnaissance in 1997. Open areas include road rights of way, harvested riparian plots, and other harvest areas with trees $<16$ years old in the watershed.

TABLE 2. Channel Characteristics (slope, width, mean depth), Streambed Sediment Particle Sizes, and Tree Basal Area in the Riparian Management Zone One Year After Forest Harvest.

\begin{tabular}{|c|c|c|c|c|c|c|c|c|}
\hline \multirow[b]{2}{*}{ Plot (number) } & \multicolumn{3}{|c|}{ Channel } & \multicolumn{4}{|c|}{ Particle Diameter at Percentile } & \multirow{2}{*}{$\frac{\text { Basal }}{\text { Area }\left(\mathbf{m}^{2} / \mathbf{h a}\right)}$} \\
\hline & Slope $(\%)$ & Width (m) & Depth (m) & D35 (mm) & D50 (mm) & D84 (mm) & D90 & \\
\hline \multicolumn{9}{|l|}{ Jack Irving Creek } \\
\hline Plot 1 & 2.3 & 1.8 & 0.40 & 0.08 & 0.09 & 1 & 50 & 18.6 \\
\hline Plot 2 & 3.0 & 2.4 & 0.15 & 0.08 & 0.09 & 1 & 23 & 15.4 \\
\hline \multicolumn{9}{|l|}{ Pokegama Creek North } \\
\hline Plot 3 & 1.4 & 1.9 & 0.21 & 0.09 & 0.10 & 65 & 128 & 20.4 \\
\hline Tributary to Plot 3 & 7.2 & 1.2 & 0.15 & 0.08 & 0.10 & 5 & 10 & - \\
\hline Plot 4 & 1.2 & 2.1 & 0.44 & 0.06 & 0.07 & 0.10 & 0.11 & 15.7 \\
\hline Plot 5 & 1.5 & 2.5 & 0.27 & 0.09 & 0.10 & 32 & 45 & 21.3 \\
\hline \multicolumn{9}{|l|}{ Pokegama Creek South } \\
\hline Plot 6 & 1.5 & 1.9 & 0.31 & 0.08 & 0.10 & 1 & 8 & 14.6 \\
\hline Plot 7 & 1.9 & 2.1 & 0.30 & 0.06 & 0.06 & 4 & 6 & 30.1 \\
\hline Plot 8 & 1.4 & 2.3 & 0.30 & 0.06 & 0.40 & 55 & 90 & 25.9 \\
\hline \multicolumn{9}{|l|}{ Little Pokegama Creek } \\
\hline Plot 10 & 1.0 & 2.3 & 0.37 & 0.16 & 0.32 & 100 & 120 & 30.3 \\
\hline Plot 11 & 2.5 & 2.9 & 0.38 & 0.09 & 0.60 & 128 & 180 & 14.4 \\
\hline Plot 12 & 2.3 & 3.0 & 0.40 & 0.09 & 0.10 & 128 & 150 & 30.4 \\
\hline
\end{tabular}

Notes: Data were collected from riffles to yield the minimum channel cross section needed for bankfull flow.

$(n=6)$. Trees were harvested in fall 1997 using either a cut-to-length harvester paired with a forwarder or a feller-buncher paired with a grapple skidder (Palik et al., 2003). Preharvest data were collected in 1997 and postharvest data were collected in 1998-2000 and 2006-2007. Each plot included 150$200 \mathrm{~m}$ of stream length, and plots were $\sim 200 \mathrm{~m}$ apart. Three reaches were sampled at each plot: $50 \mathrm{~m}$ immediately upstream of the treatment, $50 \mathrm{~m}$ immediately downstream of the treatment, and $50 \mathrm{~m}$ at the downstream end of the plot (Figure 1). Study plots were established collaboratively (Merten, 1999; Fox, 2000; Fredrick, 2003; Hanowski et al., 2003, 2007; Palik et al., 2003; Hemstad et al., 2008).

\section{Examination of Year Effects at Study Plots}

A variety of data were collected at the study plots for examination of basin-scale year effects (i.e., overall differences between years when pooling all plots regardless of treatment). Six variables were measured, as described below, to characterize streambank and channel conditions: proportion of unstable banks, canopy cover, surficial fine substrates, embeddedness, streambed depth of refusal, and residual pool depth. Visual estimates of the proportion of bank area that was unstable (not covered by vegetation, roots, or rocks) were made in the three $50-\mathrm{m}$ reaches at each plot (Merten, 1999; Hemstad et al., 2008). The value for each 50-m reach was the mean of three 17-m sections. Canopy cover was also determined at the center of each $17-\mathrm{m}$ section using a spherical concave forest densiometer in all four directions (Lemmon, 1957). Unstable banks and canopy cover were assessed in July 1997 (preharvest) through 2000 and 2006-2007.

Surficial substrates were examined in the three reaches at each of the 11 study plots. Each 50-m reach at each plot was divided into five $10-\mathrm{m}$ subreaches, to avoid sampling substrates exclusively at the upstream or downstream end of a $50-\mathrm{m}$ reach. Seven circular quadrats $(28 \mathrm{~cm}$ in diameter) were placed in random locations in each $10-\mathrm{m}$ subreach to 
visually estimate the percentage of sand, silt, or clay (i.e., fine substrates) on the streambed surface (for a total of 1,155 quadrats per year). Embeddedness was estimated in each quadrat as the degree to which larger substrates were buried in fine substrates (e.g., a quadrat with cobbles half-buried in sand was $50 \%$ embedded, whereas a quadrat with only fine substrates visible was $100 \%$ embedded). Surficial substrates were examined in July 1997-2000 and 2006-2007.

Sediment storage in the channel was evaluated using depth of refusal and residual pool depth. At each of the 11 study plots, the 10 riffles with the largest substrates and the 10 deepest pools were sampled. Depth of refusal was determined at each riffle and pool by probing with a rod to determine the thickness of the fine sediment layer (i.e., sand or silt) in the stream channel. A tapered aluminum rod was used to probe the sediment. The depth of refusal for each plot was the mean of the 10 riffles and 10 pools. Depth of refusal was measured in summer 1997, 1998, 2006, and 2007. Residual pool depth (i.e., pool depths minus riffle depths) was determined for each plot in summer 1997, 2006, and 2007 with a laser level following Lisle (1987).

In fall 2007, rain events that totaled $88 \mathrm{~mm}$ above the September/October mean for the study period caused high flows throughout the study area (Minnesota State Climatology Office, March 15, 2008). Depth of refusal data were collected at all plots in November 2007 to investigate whether sediment had been flushed from the streams by these high flows.

Previous work documented short-term effects of forest harvest on sediment in the Pokegama Creek system, and suggested that basin-scale effects were more important than local-scale effects or harvesting technique (Hemstad et al., 2008). Therefore, year effects were evaluated at all study plots, regardless of harvest treatment, using repeated-measures ANOVAs that included our new data from 2006 to 2007. Two factors were included in each analysis: a factor for year and a blocking factor for the four streams. The blocking factor was necessary to address a lack of independence between sampling units on the same stream. Variables were transformed as needed to reduce heteroscadasticity and improve normality. A repeated-measures ANOVA was examined separately for canopy coverage, unstable banks, embeddedness, and surficial fine substrates. In addition, repeatedmeasures ANOVAs were used to evaluate year effects on depth of refusal and residual pool depth, using a year factor but no blocking factor (due to greater separation between sampling units and lower temporal replication). When ANOVAs were significant $(p<$ 0.05), Tukey's HSD comparison was used to compare differences in mean values for the response variable between years. The statistical software $R$ was used for all analyses (Ihaka and Gentleman, 1996).

\section{Comparisons With Pfankuch Channel Stability Rating}

We evaluated our methods for assessing fine sediment by comparing them with the Pfankuch Channel Stability Rating (Pfankuch, 1975), an established method for assessing geomorphic stability. The rating uses qualitative categories for 15 metrics to describe conditions of streambanks and channels, and sums the values into a score from 38 (the most stable condition) to 152 (the most disturbed condition). In 2007, the Pfankuch Channel Stability Rating was determined at each of the 12 study plots, and was compared with simple regressions against our measures of surficial fine substrates, embeddedness, depth of refusal, and residual pool depth (combining data from all three reaches at each plot).

\section{RESULTS}

\section{Year Effects at Study Plots}

Canopy cover, unstable banks, embeddedness, and surficial fine substrates were significantly different across years during the study period (Table 3). Although canopy cover was unaffected by harvest itself (i.e., 1997 and 1998 were not significantly different), canopy cover declined as a result of windthrow by 2000 and had recovered to preharvest levels by 2006 (Figure 2A). The proportion of unstable banks increased between 1997 and 2000, but had recovered by 2007 (Figure 2B). Embeddedness increased from 1997 to 1998 and remained above

TABLE 3. Basin-Scale Year Effects for Canopy Cover, Unstable Banks, Embeddedness, and Surficial Fine Substrates From 1997 (preharvest) to 2007 (10 years postharvest) Using Repeated-Measures ANOVAs.

\begin{tabular}{lrccc}
\hline & d.f. & Sum of Squares & $\boldsymbol{F}$-Value & $\boldsymbol{p}$ \\
\hline Canopy cover & 5 & 450.98 & 13.0034 & $<0.001$ \\
Residual error & 152 & $1,054.33$ & & \\
Unstable banks & 5 & $5,111.7$ & 14.3824 & $<0.001$ \\
Residual error & 152 & $10,804.5$ & & \\
Embeddedness & 5 & $11,958.2$ & 30.8455 & $<0.001$ \\
Residual error & 152 & $11,785.5$ & & \\
Surficial fines & 5 & 5,325 & 13.5825 & $<0.001$ \\
Residual error & 152 & 11,919 & & \\
\hline
\end{tabular}

Notes: The significance of the year factor is shown for each response; blocking factors are not shown. 
(A)

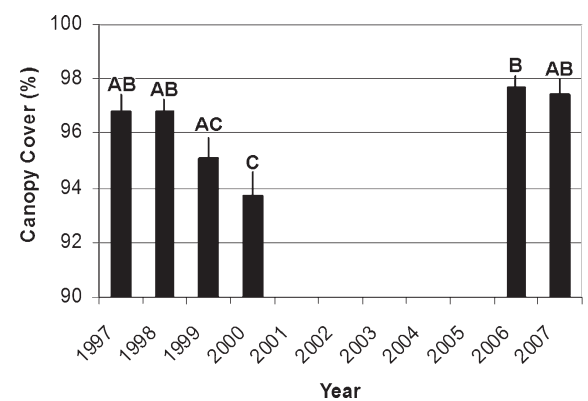

(C)

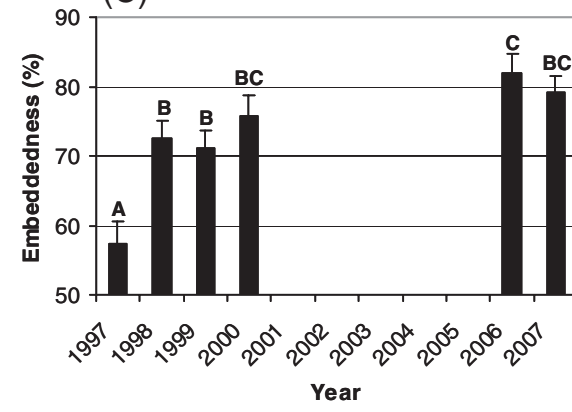

(B)

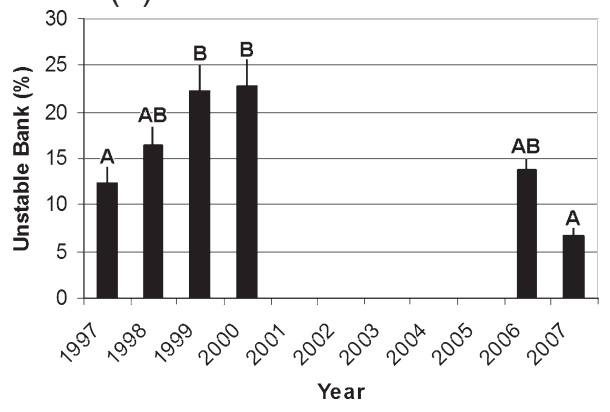

(D)

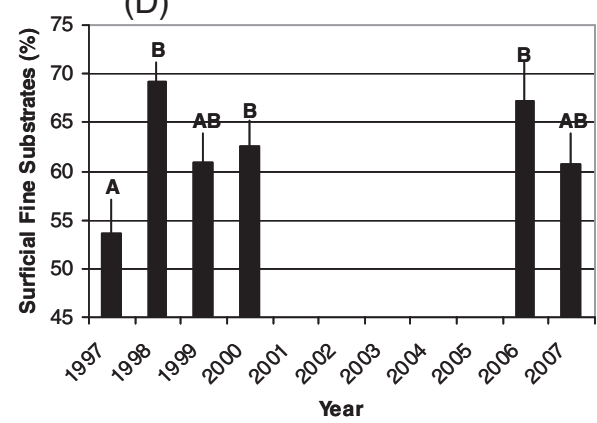

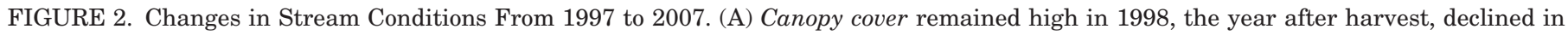
1999 and 2000 from windthrow, and recovered by 2006. (B) Unstable banks increased in the three years after harvest but recovered by 2006. (C) Embeddedness increased after harvest and remained high, (D) as did the proportion of surficial fine substrates. For all graphs, error bars are $1 \mathrm{SE}$, columns with a letter in common are not significantly different ( $p<0.05$, Tukey's HSD).

preharvest levels through 2007 (Figure 2C). Surficial fine substrates also increased from 1997 to 1998, but partially recovered in 1999 after a heavy summer storm (Figures 2D and 3). The proportion of surficial fine substrates again increased significantly relative to preharvest levels in 2000 and 2006, but recovered in 2007.

Sediment storage was also significantly different across years during the study period. Residual pool depths were shallower than preharvest conditions in both 2006 and 2007 (Figure 4A). Depth of refusal was not significantly different between 1997 and 1998 but increased significantly between 1998 and 2006, and remained significantly greater than preharvest levels in summer of 2007 (Figure 4B). However, following heavy rains in fall 2007 (Figure 3), large amounts of freshly deposited sand were noted on the floodplains and depth of refusal in November was no longer significantly different from preharvest levels (Figure 4B).

\section{Comparisons With Pfankuch Channel Stability Rating}

The Pfankuch Channel Stability Rating was correlated highly and positively with the proportion of surficial fine substrates $\left(R^{2}=0.78\right.$, Figure 5$)$. The correlations with other variables were weaker; the $R^{2}$ for embeddedness, residual pool depth, and depth of refusal were $0.40,0.31$, and 0.28 .

\section{DISCUSSION}

Our study shows that headwater streams in moraine landscapes may require 10 years to recover after a large input of fine sediment, depending on the rate of streambank revegetation and the frequency of large storm events. Our data for the proportion of surficial fine substrates were validated by the strong correlation with the Pfankuch Stream Channel Stability Rating, which includes similar assessments of surficial conditions. The weaker correlations for embeddedness, depth of refusal, and residual pool depth may simply mean that they assess different aspects of stream geomorphology, particularly the thickness of the layer of fine sediment that is not considered by the Pfankuch rating. After the input of sediment between 1997 and 1998, stream conditions remained significantly different 10 years later as indicated by embeddedness (57\% in 1997 to $79 \%$ in 2007), depth of 
Recovery of Sediment Characteristics in Moraine, Headwater Streams of Northern Minnesota After Forest Harvest
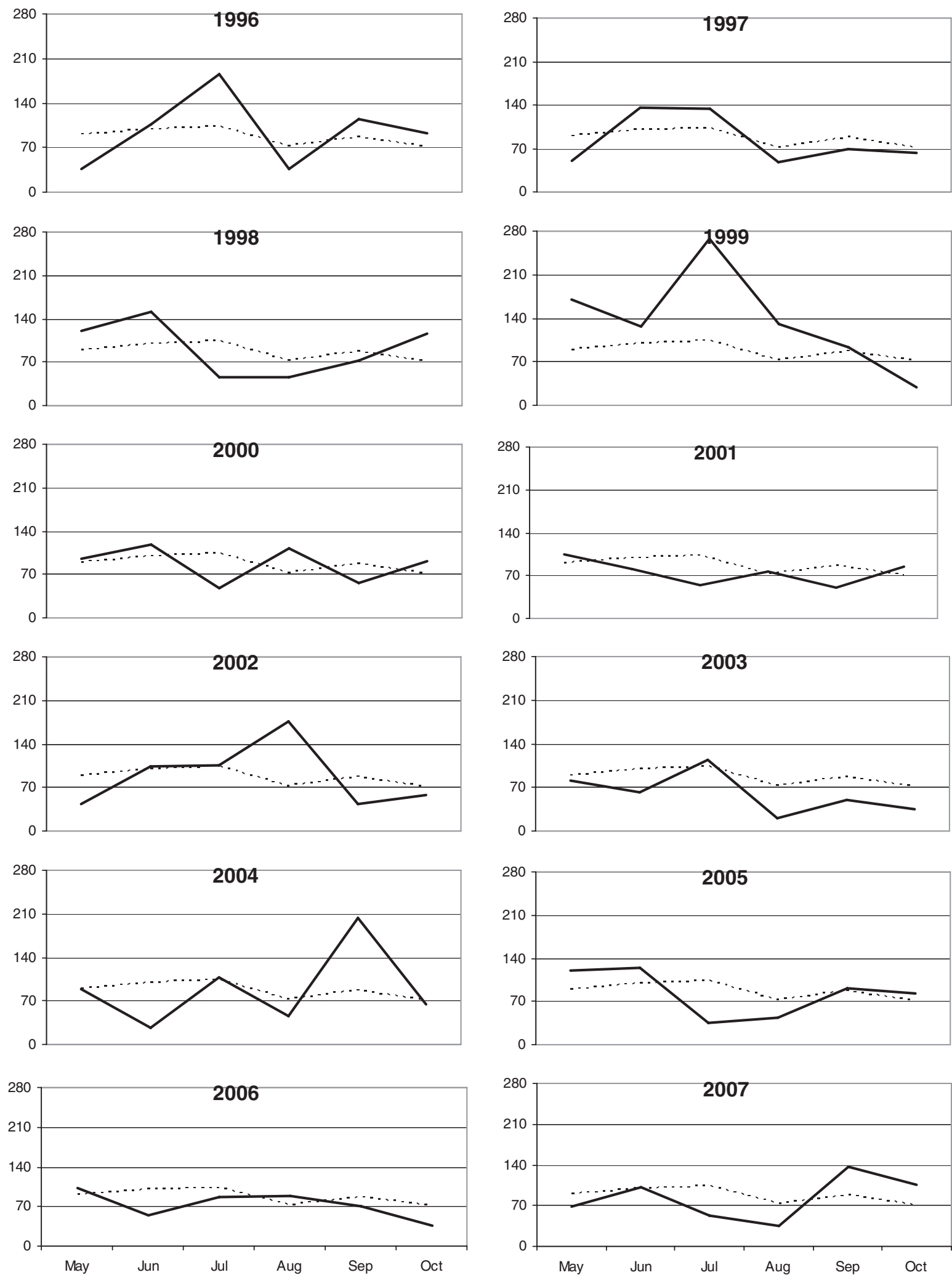

FIGURE 3. Rainfall (mm) Patterns by Month and Year for the Pokegama Creek Basin. The dashed line is the mean for the study period. 

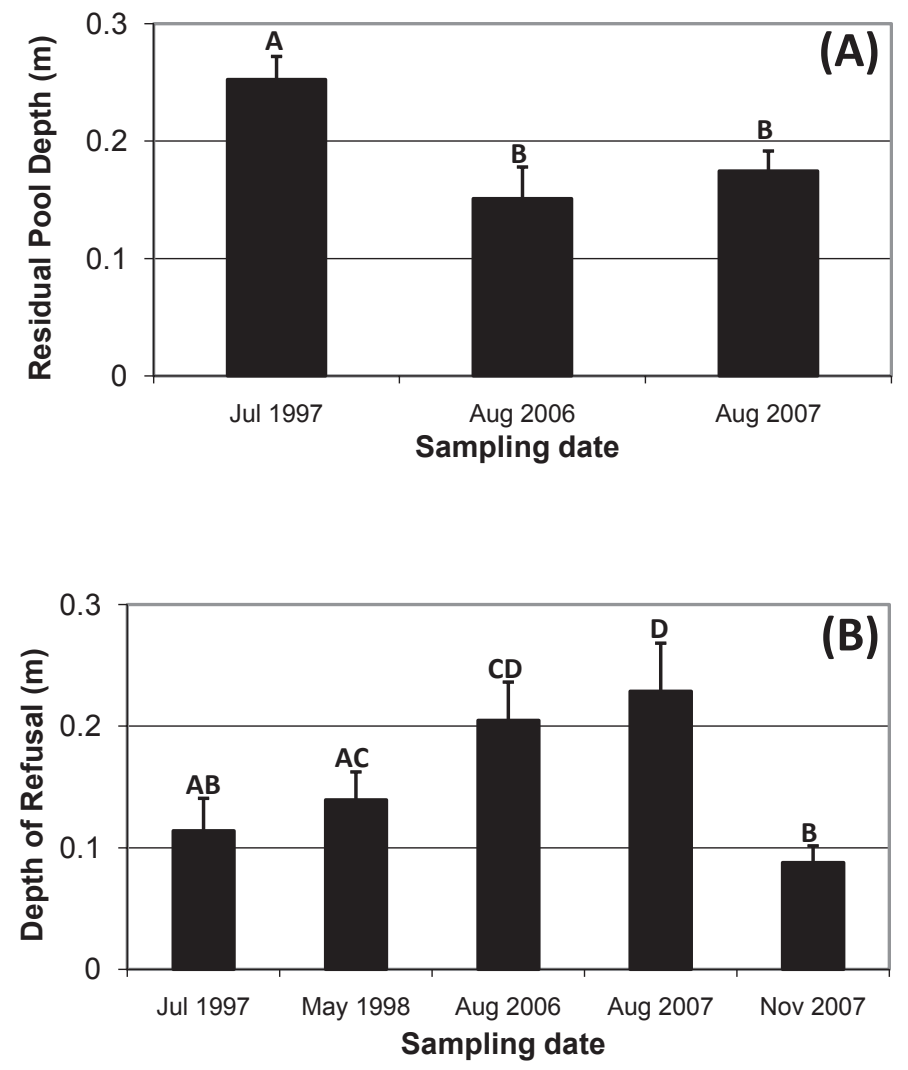

FIGURE 4. Changes in Geomorphic Conditions From 1997 to 2007. (A) Residual pool depth reflected filling with sand after the preharvest 1997 measurement, and (B) depth of refusal increased through all sample periods until after a large storm in November 2007. For all graphs, error bars are $1 \mathrm{SE}$; columns with a letter in common are not significantly different ( $p>0.05$, Tukey's HSD).

refusal $(0.11 \mathrm{~m}$ in 1997 to $0.23 \mathrm{~m}$ in summer 2007), and residual pool depth $(0.25 \mathrm{~m}$ in 1997 to $0.17 \mathrm{~m}$ in 2007). The year effects we documented may be related to changes in bank scour, windthrow, storm events, and damage from forest harvest equipment in 1997.

Bank scour throughout the study area may have contributed fine sediment through at least 2000, as evidenced by higher proportions of unstable banks. Banks were fully revegetated and stabilized by 2007 , by which time bank scour was presumably reduced. However, excess sediment (i.e., embeddedness, depth of refusal, and residual pool depth) remained in the streams through summer 2007. Storm events in fall 2007 led to high streamflows that flushed enough sediment from the stabilized channels to return depth of refusal values to 1997 conditions.

Local weather patterns can influence windthrow, sediment storage, and sediment transport (Brooks et al., 1997). Storm events occurred during 1998 and 1999, followed by a period through 2001 with no major storm events when sediment likely stayed in the channel. Heavy rainfall events occurred again in 2002 and 2004, including summer storms with high winds that may have caused windthrow and inputs of associated sediment (Grizzel and Wolff, 1998) along with bank scour from unstable banks. Another period of relatively low storm frequency followed from 2005 through mid-2007 when sediment likely remained in the channel, until the storms of fall 2007 flushed the sediment from the stabilized channels. The analysis of decade-long studies should be interpreted in the context of such weather cycles.

Windthrow along the channel banks (Hemstad et al., 2008) may also have led to increases in unstable banks and channel sediment (Grizzel and Wolff, 1998). Rootwads exposed by windthrow influenced channel morphology in places by adding associated sediment, partially blocking the channel, and inducing bank cutting around the rootwad. Studies of windthrow in riparian buffers in the upper Midwest are rare (Heinselman, 1955, 1957; Elling and Verry, 1978) but suggest that windthrow rates are greatest near the edge of buffers (sensu Martin and Grotfendt, 2007), thus wider buffers protect streamside trees from windthrow by increasing the distance between the streamside trees and the edge of the buffer.

The streams in the Pokegama Creek system may have experienced increases in bankfull discharge due to increases in water yield from harvested areas (Brooks et al., 1997; Macdonald et al., 2003; Verry, 2004; Detenbeck et al., 2005; Moore and Wondzell, 2005; Waterloo et al., 2007). Although the harvested percentages of the four subcatchments were only $2-11 \%$, Serengil et al. (2007b) found hydrologic effects after $11 \%$ of a basin was harvested. Lower thresholds may simply be precluded by the accuracy of hydrologic measurements (Verry, 1986). Hemstad et al. (2008) found few plot-level effects of forest harvest in the Pokegama Creek system from 1997 to 2000 , but suggested that basin-scale changes may have masked impacts at the plot level. Hemstad and Newman (2006) also found few plot-level effects in the Knife River basin in northeast Minnesota, but observed basin-scale increases in unstable banks and surficial fine substrates 0-2 years after forest harvest. It is noteworthy that the greatest changes in surficial fine substrates and embeddedness during the study period occurred immediately after forest harvest, indicating a possible response to altered hydrology or soil disturbance from harvesting equipment.

Small tributary channels, if impacted by harvesting equipment, can also contribute to sediment loading in mainstem channels. Study Plot 3 contained a small, yet steep (7.2\%) intermittent tributary $1.2 \mathrm{~m}$ 

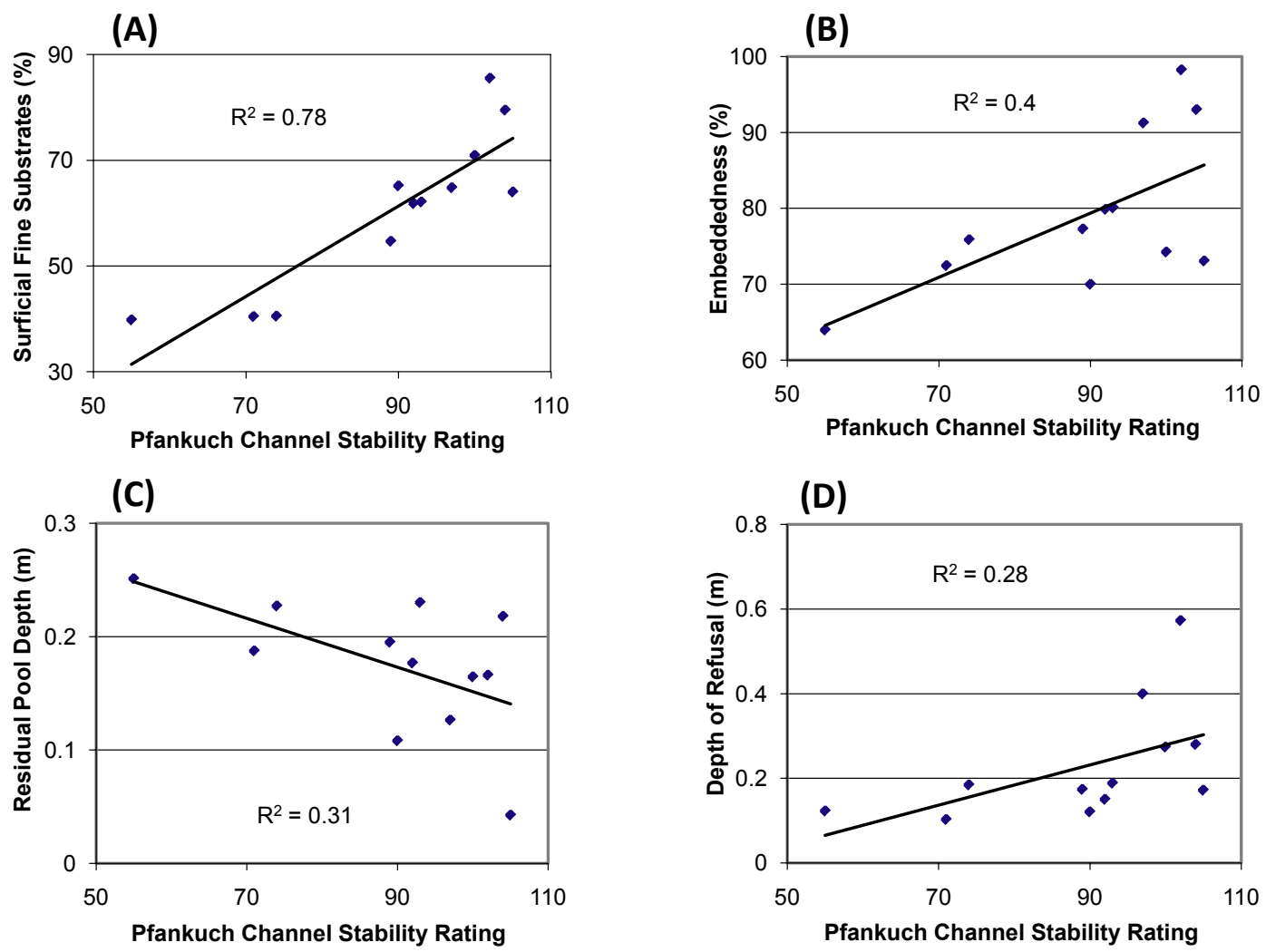

FIGURE 5. Comparison from 2007 for Pfankuch Channel Stability Ratings Against (A) Proportion of Surficial Fine Substrates, (B) Embeddedness, (C) Residual Pool Depth, and (D) Depth of Refusal.

wide and $15 \mathrm{~cm}$ deep that was crossed repeatedly with harvesting equipment (sensu unrestricted harvest treatment of Keim and Schoenholtz, 1999). The machine traffic broke down the banks and razed the intermittent channel. In subsequent years, the channel was reformed by bankfull discharges, delivering large amounts of fine sand into the mainstem of Pokegama Creek North. The pool in Pokegama Creek North just below the confluence of the tributary was nearly filled with sediment $(89 \%$ loss of crosssectional area) and the mean depth was reduced by 82\% (Elon S. Verry, Ellen River Partners, 2008, unpublished data). Use of a temporary bridge at a designated crossing site on the intermittent tributary would likely have preserved channel dimensions and prevented sediment delivery to the mainstem channel. Minnesota's voluntary guidelines for forest harvest now recommend such crossings for intermittent channels as well as perennial channels (Minnesota Forest Resources Council, 2005). It bears mention that the mainstem channels in the Pokegama Creek system are themselves tributaries; sediment flushed from them may have altered habitat conditions downstream.

\section{CONCLUSION}

Previous research has shown that headwater streams can be negatively impacted by fine sediment following riparian logging and concomitant changes in land use in the catchment (Kreutzweiser and Capell, 2001; Gomi et al., 2005; Hemstad et al., 2008). Although our study did not separately quantify changes due to forest harvest, stream crossings, windthrow, or natural causes, we evaluated recovery after a large input of fine sediment. Our study shows that moraine, headwater streams can require an extended period (up to 10 years) and an enabling event (e.g., high storm flows) to recover from large inputs of fine sediment. Although study plots were relatively small (4.9 ha) and retained some riparian trees, we observed basin-scale year effects for fine sediment in the stream channels that are consistent with forest harvest effects documented elsewhere (Gomi et al., 2005).

Some recommendations may help mitigate loading of fine sediment following forest harvest. First, we concur with others (e.g., Brooks et al., 1997; 
Verry, 2004; Detenbeck et al., 2005) that it is wise to minimize alterations to hydrology and bank scour by reducing the percentage of the basin that is harvested. Second, impacts of roads and crossings should be minimized, such as by preventing machine traffic within a riparian buffer (Keim and Schoenholtz, 1999; Lacey, 2000). When crossings are necessary, erosion control measures should be taken and bridge spans or culverts should be large enough to accommodate storm flows without causing backwater effects or hydraulic contraction (Johnson, 2002). Similarly, harvesting and forwarding around and across intermittent stream channels should use temporary bridges at designated crossing points to protect the streambanks (Minnesota Forest Resources Council, 2005). Our third recommendation is to manage riparian areas for sustainable stocks, where the annual growth increment exceeds the losses due to windthrow. Forests, and streams, can provide a variety of products and ecological services (Neuman, 2007). Continued research on recovery times from sediment inputs, whatever the source, can allow more informed decisions about forest management.

\section{ACKNOWLEDGMENTS}

This work was funded by the Minnesota Department of Natural Resources Division of Fisheries, the Minnesota Forest Resources Council, the National Council for Air and Stream Improvement, the U.S. Forest Service, the Minnesota Environment and Natural Resources Trust Fund, and Minnesota Trout Unlimited. Charlie Blinn and Brian Palik selected the study plots and supervised the manipulations. John Hansen and Jim Marshall of UPM-Kymenne Corporation Blandin provided access to the study plots. Forest harvest was completed by Rieger Logging. We sincerely thank the following for assistance with data collection: Andy Arola, Brenda Asmus, Jason Bronk, Rebecca Bronk, Ryan Carlson, Bill Coates, Jacquelyn Conner, Carrie Dorrance, Art Elling, MaryKay Fox, Jo Fritz, Sarah Harnden, Deacon Kyllander, Marty Melchior, Steffen Merten, Mateya Miltich, Brittany Mitchell, Erik Mundahl, Elliot Nitzkowski, Ian Phelps, Lisa Pugh, Jeff Rice, David Schroeder, Jeremy Steil, Dustin Wilman, and Jason Zwonitzer. The Statistical Consulting Service at the University of Minnesota provided R code for analysis. Comments from Jacques Finlay, Heinz Stefan, and three anonymous reviewers improved the quality of the manuscript. The Minnesota Cooperative Fish and Wildlife Research Unit is jointly sponsored by the U.S. Geological Survey, the University of Minnesota, the Minnesota Department of Natural Resources, and the Wildlife Management Institute.

\section{LITERATURE CITED}

Broadmeadow, S. and T.R. Nisbet, 2004. The Effects of Riparian Forest Management on the Freshwater Environment: A Literature Review of Best Management Practice. Hydrology and Earth System Sciences 8:286-305.
Brooks, K.N., P.F. Folliot, H.M. Gregersen, and L.F. DeBano, 1997. Hydrology and the Management of Watersheds. Iowa State University Press, Ames, Iowa.

Chamberlin, T.W., R.D. Harr, and F.H. Everest, 1991. Timber Harvesting, Silviculture, and Watershed Processes. In: Influences of Forest and Rangeland Management on Salmonid Fisheries and Their Habitats, W.R. Meehan (Editor). American Fisheries Society, Bethesda, Maryland, pp. 181-206.

Davies, P.E. and M. Nelson, 1994. Relationships Between Riparian Buffer Widths and the Effects of Logging on Stream Habitat, Invertebrate Community Composition and Fish Abundance. Journal of Marine and Freshwater Research 45:1289-1305.

Detenbeck, N.E., V.J. Brady, D.L. Taylor, V.M. Snarski, and S.L. Batterman, 2005. Relationship of Stream Flow Regime in the Western Lake Superior Basin to Watershed Type Characteristics. Journal of Hydrology 309:258-276.

Elling, A.E. and E.S. Verry, 1978. Predicting Wind-Caused Mortality in Strip-Cut Stands of Peatland Black Spruce. The Forestry Chronicle 54:249-252.

Fox, M., 2000. Biomonitoring and Best Management Practices in Northern Minnesota: Implications for Riparian Management. Masters thesis, University of Minnesota, St. Paul, Minnesota.

Fredrick, K.E., 2003. Impacts of Forestry Best Management Practices on Water Quality and Benthic Macroinvertebrates. Masters thesis, University of Minnesota, St. Paul, Minnesota.

Gomi, T., R.D. Moore, and M.A. Hassan, 2005. Suspended Sediment Dynamics in Small Forest Streams of the Pacific Northwest. Journal of the American Water Resources Association 41:877-898.

Gomi, T., R.C. Sidle, S. Noguchi, J.N. Negishi, A.R. Nik, and S. Sasaki, 2006. Sediment and Wood Accumulations in Humid Tropical Headwater Streams: Effects of Logging and Riparian Buffers. Forest Ecology and Management 224:166-175.

Grizzel, J.D. and N. Wolff, 1998. Occurrence of Windthrow in Forest Buffer Strips and Its Effect on Small Streams in Northwest Washington. Northwest Science 72:214-223.

Hanowski, J., N. Danz, and J. Lind, 2007. Breeding Bird Response to Riparian Forest Management: 9 Years Post-Harvest. Forest Ecology and Management 241:272-277.

Hanowski, J., N. Danz, J. Lind, and G. Niemi, 2003. Breeding Bird Response to Riparian Forest Harvest and Harvest Equipment. Forest Ecology and Management 174:315-328.

Heinselman, M.L., 1955. Timber Blowdown Hazard in the Rainy River Section of Northern Minnesota. U.S. Department of Agriculture, Forest Service, North Central Forest Experiment Station, St, Paul, Minnesota, Technical Note 433.

Heinselman, M.L., 1957. Wind-Caused Mortality in Minnesota Black Spruce in Relation to Cutting Methods and Stand Conditions. Proceedings of the Society of American Foresters 1957:7477.

Hemstad, N.A., E.C. Merten, and R.M. Newman, 2008. Effects of Riparian Forest Thinning by Two Types of Mechanical Harvest on Stream Fish and Habitat in Northern Minnesota. Canadian Journal of Forest Research 38:247-256.

Hemstad, N.A. and R.M. Newman, 2006. Local and Landscape Effects of Past Forest Harvest on Stream Habitat and Fish Assemblages. In: Influences of Landscape on Stream Habitat and Biological Assemblages, R.M. Hughes, L. Wang, and P.W. Seelbach (Editors). American Fisheries Society, Bethesda, Maryland, pp. 413-427.

Ihaka, R. and R. Gentleman, 1996. R: A Language for Data Analysis and Graphics. Journal of Computational and Graphical Statistics 5:299-314.

Johnson, A.C., R.T. Edwards, and R. Erhardt, 2007. Ground-Water Response to Forest Harvest: Implications for Hillslope Stability. Journal of the American Water Resources Association 43:134147. 
Johnson, P.A., 2002. Incorporating Road Crossings Into Stream and River Restoration Projects. Ecological Restoration 20:207-277.

Keim, R.F. and S.H. Schoenholtz, 1999. Functions and Effectiveness of Silvicultural Streamside Management Zones in Loessial Bluff Forests. Forest Ecology and Management 118:197-209.

Kreutzweiser, D.P. and S.S. Capell, 2001. Fine Sediment Deposition in Streams After Selective Forest Harvesting Without Riparian Buffers. Canadian Journal of Forest Research 31, 2134-2142 (see also erratum Canadian Journal of Forest Research 32:1108).

Lacey, S.T., 2000. Runoff and Sediment Attenuation by Undisturbed and Lightly Disturbed Forest Buffers. Water, Air, and Soil Pollution 122:121-138.

Lemmon, P.E., 1957. A New Instrument for Measuring Forest Overstory Density. Journal of Forestry 55:667-668.

Lisle, T.E., 1987. Using "Residual Depths" to Monitor Pool Depths Independently of Discharge. Research Note PSW-394, Pacific Southwest Forest and Range Experiment Station, USDA Forest Service, Berkeley, California.

Macdonald, J.S., P.G. Beaudry, E.A. MacIsaac, and H.E. Herunter, 2003. The Effects of Forest Harvesting and Best Management Practices on Streamflow and Suspended Sediment Concentrations During Snowmelt in Headwater Streams in Sub-Boreal Forests of British Columbia, Canada. Canadian Journal of Forest Research 33:1397-1407.

Martin, D. and R. Grotfendt, 2007. Stand Mortality in Buffer Strips and the Supply of Woody Debris to Streams in Southeast Alaska. Canadian Journal of Forest Research 37:36-49.

Merten, E., 1999. Effects of Forest Harvest on Coldwater Stream Fish and Habitat in Northern Minnesota. Masters thesis, University of Minnesota, St. Paul, Minnesota.

Minnesota Forest Resources Council, 2005. Sustaining Minnesota Forest Resources: Voluntary Site-Level Forest Management Guidelines for Landowners, Loggers and Resource Managers. Minnesota Forest Resources Council, St. Paul, Minnesota.

Moore, R.D. and S.M. Wondzell, 2005. Physical Hydrology and the Effects of Forest Harvesting in the Pacific Northwest: A Review. Journal of the American Water Resources Association 41:763784 .

Neuman, J.C., 2007. Thinking Inside the Box: Looking for Ecosystem Services Within a Forested Watershed. Journal of Land Use \& Environmental Law 22:173-205.

Nyberg, P.R., 1987. Soil Survey of Itasca County, Minnesota. Soil Survey, U.S. Department of Agriculture, Soil Conservation Service, Forth Worth, Texas.

Palik, B., K. Ceases, and L. Egeland, 2003. Aspen Regeneration in Riparian Management Zones in Northern Minnesota: Effects of Residual Overstory and Harvest Method. Northern Journal of Applied Forestry 20:79-84.

Pfankuch, D.J., 1975. Stream Reach Inventory and Channel Stability Evaluation. R1-75-002. USDA Forest Service, Washington, D.C.

Serengil, Y., F. Gokbulak, S. Ozhan, A. Hizal, and K. Sengonul, 2007a. Alteration of Stream Nutrient Discharge With Increased Sedimentation Due to Thinning of a Deciduous Forest in Istanbul. Forest Ecology and Management 246:264-272.

Serengil, Y., F. Gokbulak, S. Ozhan, A. Hizal, K. Sengonul, A.N. Balci, and N. Ozyuvaci, 2007b. Hydrological Impacts of a Slight Thinning Treatment in a Deciduous Forest Ecosystem in Turkey. Journal of Hydrology 333:569-577.

Steedman, R.J. and R.L. France, 2000. Origin and Transport of Aeolian Sediment From New Clearcuts Into Boreal Lakes, Northwestern Ontario, Canada. Water, Air, and Soil Pollution 122:139-152.

Sweka, J.A. and K.J. Hartman, 2001. Influence of Turbidity on Brook Trout Reactive Distance and Foraging Success. Transactions of the American Fisheries Society 130:138-146.
Thompson, R.M., N.R. Phillips, and C.R. Townsend, 2009. Biological Consequences of Clear-Cut Logging Around Streams - Moderating Effects of Management. Forest Ecology and Management 257:931-940.

Verry, E.S., 1986. Forest Harvesting and Water: The Lake States Experience. Water Resources Bulletin 22:1039-1047.

Verry, E.S., 2004. Land Fragmentation and Impacts to Streams and Fish in the Central and Upper Midwest, Ch. 5. In: A Century of Forest and Wildland Watershed Lessons, G.G. Ice and J.D. Stednick (Editors). Society of American Foresters, Bethesda, Maryland, pp. 129-154.

Waterloo, M.J., J. Schellekens, L.A. Bruijnzeel, and T.T. Rawaqa, 2007. Changes in Catchment Runoff After Harvesting and Burning of a Pinus Caribea Plantation in Viti Levu, Fiji. Forest Ecology and Management 251:31-44.

Waters, T.F., 1995. Sediment in Streams: Sources, Biological Effects, and Control. American Fisheries Society monograph 7 , Bethesda, Maryland.

Wondzell, S.M., 2001. The Influence of Forest Health and Protection Treatments on Erosion and Stream Sedimentation in Forested Watersheds of Eastern Oregon and Washington. Northwest Science 75:128-140. 